OPEN ACCESS

Edited by:

Sachin Kumar

Sardar Swaran Singh National Institute of Renewable Energy, India

Reviewed by:

Anju Arora

Indian Agricultural Research Institute

(ICAR), India

Eeshan Kalita,

Tezpur University, India

*Correspondence:

Hyeun-Jong Bae

baehj@chonnam.ac.kr

Specialty section:

This article was submitted to

Bioenergy and Biofuels,

a section of the journal

Frontiers in Energy Research

Received: 07 November 2019

Accepted: 19 February 2020

Published: 06 March 2020

Citation:

Lee D-S, Lee Y-G, Song Y, Cho E-J and Bae H-J (2020) Hydrolysis

Patterns of Xylem Tissues of

Hardwood Pretreated With Acetic

Acid and Hydrogen Peroxide.

Front. Energy Res. 8:34.

doi: 10.3389/fenrg.2020.00034

\section{Hydrolysis Patterns of Xylem Tissues of Hardwood Pretreated With Acetic Acid and Hydrogen Peroxide}

\author{
Dae-Seok Lee ${ }^{1}$, Yoon-Gyo Lee ${ }^{1}$, Younho Song ${ }^{1}$, Eun-Jin Cho ${ }^{1}$ and Hyeun-Jong Bae ${ }^{1,2 *}$ \\ ${ }^{1}$ Bio-Energy Research Center, Chonnam National University, Gwangju, South Korea, ${ }^{2}$ Department of Bioenergy Science and \\ Technology, College of Agriculture and Life Sciences, Chonnam National University, Gwangju, South Korea
}

The structural recalcitrance of lignocellulose limits its enzymatic hydrolysis, which leads to inefficient enzyme usage and inhibition of saccharification, depending on the pretreatment method. Research on the structural properties of xylem tissues of hardwood and their effect on enzymatic saccharification is necessary to achieve cost-effective biofuel production via improved enzyme cocktail preparation. Oak wood (Quercus acutissima) was pretreated and delignified with a hydrogen peroxide-acetic acid (HPAC) solution. Cellulose was found to undergo significant swelling in the lumen of the wood fiber, and it was sorted into readily hydrolysable (72.9\%), mid-hydrolysable (8.2\%), and hardly hydrolysable (18.9\%) cellulose forms. Oak wood has been shown to be strongly retarded among the various types of hardwoods. The recalcitrance of the xylem tissues, such as wood fibers, tracheids, vessel elements, and ray parenchyma cells, was determined through analysis of the hydrolysis rates. It was found to increase in the following order: ray parenchyma cells $<$ tracheids $<$ wood fibers or vessel elements $<$ tracheids $<$ wood fibers. The wood fibers were almost enzymatically fragmented into pieces $\sim 90 \mu \mathrm{m}$ in length at crack sites in $6 \mathrm{~h}$. The wood fibers were digested faster in the $S_{3}$ or $S_{2}$ wall than in the primary wall. The result indicated that the primary wall may be a structural retardation factor in the hardwood as sorted to the hardly hydrolysable cellulose. In presence of $10 \%$ substrate supplemented with enzymes to reduce the structural recalcitrance (xylanase and lytic polysaccharide monoxygenase) and end-product inhibitions (beta-glucosidase), the hydrolysis rate was increased by $55.21 \%$. Ethanol fermentation exhibited a higher efficiency when a single substrate $(Q$. acutissima) rather than a mixture of various hardwoods was used. Of all the xylem tissues of hardwood that were delignified by HPAC pretreatment, wood fiber was found to be a structural retardation factor owing to the recalcitrance its primary wall. Thus, enzyme preparation can enable the rapid and efficient hydrolysis for the commercialization of bioethanol from hardwood.

Keywords: structural recalcitrance, cellulose, hardwood, xylem tissues, enzymatic hydrolysis, rapid saccharification, pretreatment 


\section{INTRODUCTION}

Based on the presence of complex polymeric structures, such as lignin, hemicellulose, and cellulose, the recalcitrance of lignocellulosic materials involves the following three main stages: lignin interference, cellulose structural retardation (amorphous and crystalline), and end-product inhibition of cellulase activity (Hall et al., 2010; Rahikainen et al., 2011; Murphy et al., 2013; Vermaas et al., 2015; Zhang et al., 2018). Highly oxygenated aromatic lignin polymers inhibit cellulose swelling during pretreatment, and the complex structure adsorbs cellulase and blocks the access of the cellulase onto the cellulose fibers of biomass during enzymatic hydrolysis. Cellulose, at the level of the microfibril structure, consists of amorphous and crystalline regions. The former regions are highly degradable, but the latter regions have a different hydrolysis rate depending on whether the pretreatment involves natural crystalline cellulose (cellulose I) that is convertible to cellulose II or III. Crystalline celluloses having different hydrogen-bonding networks between cellulose chains exhibit different rates of enzymatic hydrolysis. The hydrolysis rate decreases in the following order: cellulose III > cellulose II > cellulose I (Igarashi et al., 2007). Some pretreatments require post-treatment for generating more hydrolyzable cellulose structures and increasing the hydrolysis rate (Kumar et al., 2011). End-product inhibition of the cellulases from Acremonium thermophilum, Thermoascus aurantiacus, Chaetomium thermophilum, and Trichoderma reesei have been investigated (Teugjas and Valjamae, 2013).

The cellulolytic enzymes of $T$. reesei include two cellobiohydrolases (CBHs: Cel7A and Cel6A, which account for $68-80 \%$ of the secretome), several endoglucanases (EGs: Cel7B, Cel5A, Cel12A, Cel61A, Cel45A, Cel74A, Cel61B, and Cel5B; $10-15 \%)$, and few other enzymes [ $\beta$-glucosidase, xylanases, and helping enzymes, e.g., arabinofuranosidases, esterases, lytic polysaccharide monoxygenases (LPMOs)] (Herpoel-Gimbert et al., 2008; Chundawat et al., 2011). CBHs release cellobiose from the ends of insoluble cellulose chains (from the reducing end by Cel7A, and from the non-reducing end by Cel6A) through their tunnel-shaped active sites via the "processive action," which has been established using the surface erosion model for the degradation of cellulose (Valjamae et al., 1998). $\mathrm{CBH}$ are strongly inhibited by end-products such as cellobiose, glucose, and xylooligomers (Gruno et al., 2004; Qing et al., 2010; Baumann et al., 2011). In particular, the inhibition of Cel7A by cellobiose (rather than the inhibition of Cel6A by glucose) is a representative retardation factor (Murphy et al., 2013). The mechanism of cellobiose inhibition was reported to occur in such a way that cellobiose combines with tryptophan residue located near the active site of Cel7A and prevents the entrance of cellulose chains into the tunnel-shaped active sites, which induces conformation changes in the enzymes and non-productive adsorption (Yue et al., 2004). These

Abbreviations: HPAC, hydrogen peroxide-acetic acid; ASC, acidified sodium chlorite; PA, phosphoric acid; FPT 60 or 100, fractions passing through the 60 or 100 mesh. reports indicate why supplementation with $\beta$-glucosidase is necessary.

The enzymatic hydrolysis of lignocellulosic biomass has been researched with regard to the enzyme attack on the microfibril or a single strand of the $\beta$-1,4-glucose chain. However, there have been few studies on enzymatic hydrolysis at the level of the microscopic structure. Clarke et al. (2011) examined the relationship between fiber dislocations and fiber cutting in the enzymatic hydrolysis of softwood, and suggested that fiber cutting may accelerate the enzymatic hydrolysis through pretreatments that generate dislocation sites. Arantes et al. (2014) revealed various patterns in hardwood or softwood fibers, such as changes in fiber cutting and fiber width during enzymatic hydrolysis. Thygesen et al. (2011) found that dislocations are not amorphous but crystalline in filter paper fiber (softwood tracheids), and that endo-glucanase (Family GH45 from Uumicola insolens) is bound strongly to the dislocation sites as well as to the loosened parts of softwood and wheat fiber. These studies indicated that the digestibility of cellulose is not determined solely by the crystallinity index in terms of the structural retardation of cellulose (Igarashi et al., 2011; Thygesen et al., 2011; Arantes et al., 2014).

Anatomically, hardwood consists of wood fibers (libriform fibers and fiber tracheids), tracheids (vascular and vasicentric tracheids), parenchyma cells (ray and longitudinal parenchyma), and vessel elements in the sap and heart wood. In some hardwoods, such as birch (Betula verrucosa), beech (Fagus sylvestris), and ash (Fraxinus exicelsior), the xylem tissues are composed of $64.8,37.4$, and $62.3 \%$ wood fiber, respectively; $24.7,31.0$, and $12.1 \%$ vessels, respectively; $8.5,27.0$, and $14.9 \%$ ray cells, respectively; and 2.0, 4.6, and $10.6 \%$ longitudinal parenchyma cells, respectively (Monica et al., 2009). The vessel and ray volumes in the yellow poplar tree was found to be $\sim 42.75$ and $11.80 \%$, respectively (Taylor, 1968). Oak wood (Quercus acutissima) is composed of $14.3 \%$ vessel elements, $62.4 \%$ wood fibers, $7.2 \%$ longitudinal parenchyma cells, and $16.1 \%$ medullary ray cells, as reported in the textbook "Wood Anatomy and Classification" (Text in Korean). The hydrolysis rates of the tissues have not been evaluated thus far. Analysis of the hydrolysis patterns of the xylem tissues provides a greater understanding of efficient saccharification in biofuel production.

Pretreatment produces a wide range of properties of the cellulose at the level of the microfibril, as well as the microscopic structure, depending on the reaction conditions and results in different hydrolysis rates (Cara et al., 2006; Zhang et al., 2018). Hydrogen peroxide-acetic acid (HPAC) treatment is a simple method to achieve lignin removal and allows cellulose to achieve highly efficient saccharification of softwood and hardwood (Wi et al., 2015). In this study, the reason for the highly efficient hydrolysis in HPAC-pretreatment of oak was analyzed with regard to the cellulose structural modification and the retardation factors during enzymatic hydrolysis, compare with other methods such as popping, acidified sodium chlorite (ASC) treatment, and phosphoric acid (PA) treatment. To better understand the hydrolysis patterns of hardwoods, anatomical tissues isolated from oak were digested and the degradation patterns were assessed. 


\section{MATERIALS AND METHODS \\ Enzyme Preparation}

Cellulase from Hypocrea jecorina (T. reesei) was produced in Czapek dox media $\left(0.2 \% \mathrm{KH}_{2} \mathrm{PO}_{4}, 0.42 \%\left(\mathrm{NH}_{4}\right)_{2} \mathrm{SO}_{4}, 0.03 \%\right.$ $\mathrm{MgSO}_{4}, 0.03 \% \mathrm{CaCl}_{2}, 0.1 \%$ peptone, $1 \%$ glucose, $0.2 \%$ trace element solution $\left(0.1 \% \mathrm{MnSO}_{4}, 0.2 \% \mathrm{CoCl}_{2}, 0.14 \% \mathrm{ZnSO}_{4}, 0.5 \%\right.$ $\mathrm{FeSO}_{4}$ ), $1 \%$ glucose, $0.02 \%$ urea, and $2 \%$ Tween 80 . The $100 \mathrm{~L}$ bioreactor (KobioTech, South Korea) was operated at $400 \times$ $\mathrm{g}$ and $28^{\circ} \mathrm{C}$ for 8 days. The cellulase expression was induced by the addition of $1 \%(\mathrm{w} / \mathrm{v})$ avicel. The airflow rate and $\mathrm{pH}$ adjustment were autoregulated to $1 \mathrm{vvm}$ and $\mathrm{pH} 4.8$, respectively. The harvested cellulase was measured to be $1.5 \mathrm{FPU}$ when 10 $\mu \mathrm{L}$ of the cellulase was applied to $50 \mathrm{mg} \mathrm{mL}^{-1}$ Whatman No.1 filter paper strip $(1.0 \times 6.0 \mathrm{~cm})$ according to the measurement of cellulase activity on filter paper.
Xylanase (Xyl) of T. longibrachiatum (Cat. X2629) was purchased from Sigma- Aldrich. GH61-Auxiliary activity family 9 (AA9) copper-dependent lytic polysaccharide monooxygenases (LPMOs) of Gloeophyllum trabeum was cloned (GeneBank accession number: AEJ35168) and the recombinant enzymes were produced in Pichia pastoris with pPICZ $\alpha \mathrm{A}$ expression vector (Invitrogen, Carlsbad, CA, USA). The enzyme was purified with Ni-NTA column (Qiagen Hilden, Germany). Quantification of the enzyme was carried out using Bradford assay. Betaglucosidase (Bgl) of Aspergillus niger was purchased from Megazyme Inc. (Lot 141001, Ireland).

\section{Pretreatment}

Popping pretreatment on oak wood was conducted via a previously reported method (Wi et al., 2011). The pretreatment
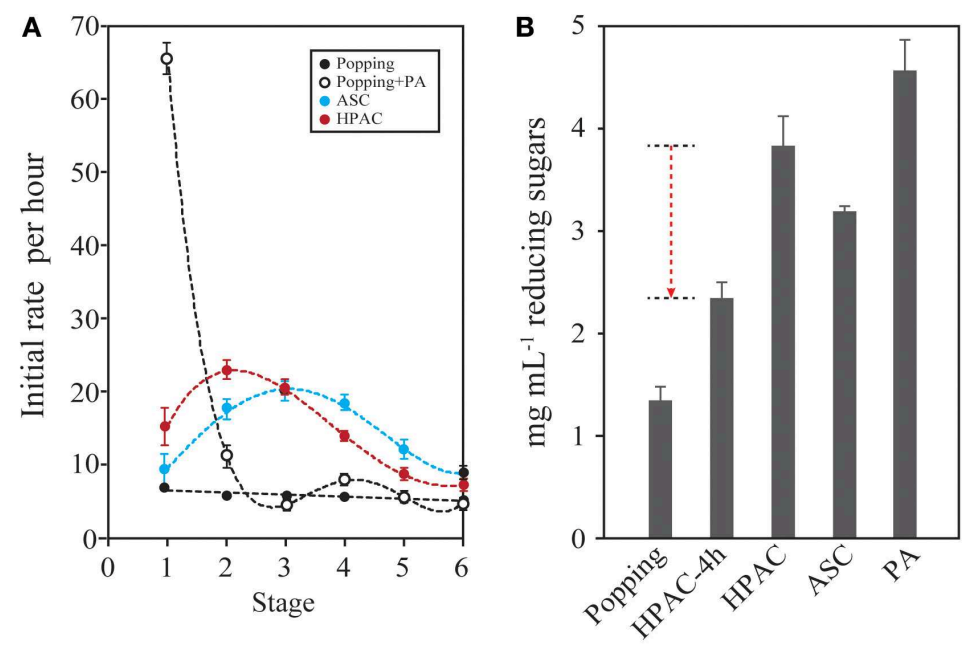

C
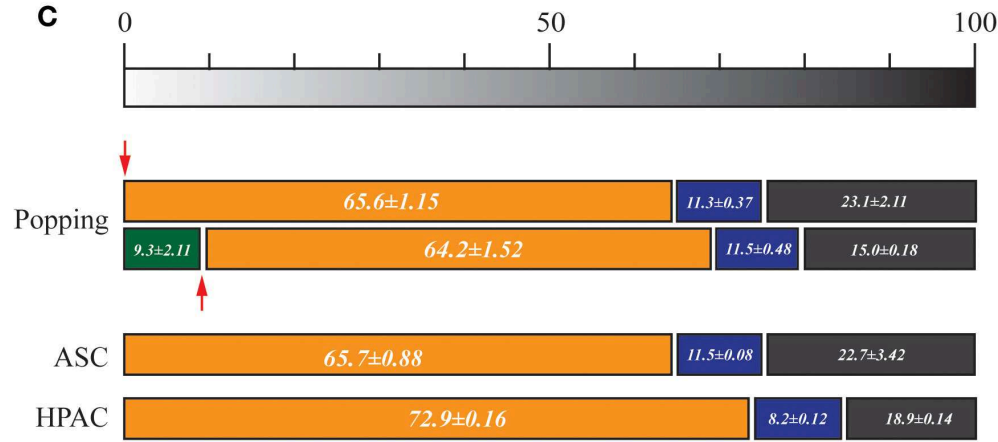

FIGURE 1 | Determination of the ratio of recalcitrant cellulose in oak wood. (A) To estimate the cellulose structural retardation during the enzymatic hydrolysis, re-hydrolysis was performed with $1 \%\left(\mathrm{~g} \mathrm{v}^{-1}\right) \mathrm{PA}, \mathrm{ASC}$, and HPAC pretreated oak. Each stage was conducted with $3.5 \mathrm{FPU}$ at $50^{\circ} \mathrm{C}$ for $1 \mathrm{~h}$. A new stage was started with the remaining solid fraction after the hydrolysis with fresh enzyme. The hydrolysis patterns during re-hydrolysis were shown to be little different between HPACand ASC-pretreated oak ( $p=0.823)$, but the significant hydrolysis rate were appeared at the first stage of phosphoric acid treated oak ( $p=<0.001)$. The most retardation during the hydrolysis occurred in popping-pretreated oak $(p<0.050)$. (B) To investigate the end-product inhibition at the early stage, the sum of reducing sugars up to the 4th stage (popping, HPAC, ASC, and PA) in (A) was compared with the concentration of reducing sugars produced by the reaction over $4 \mathrm{~h}$ (HPAC-4 h). The red dotted arrow indicates reduction via end-product inhibition. (C) Determination of the cellulose structural retardation factor. Popping-pretreated oak was hydrolyzed for $1 \mathrm{~h}$ (green bar). PA was treated for amorphogenesis (red arrow). The bars represent the cellulose types based on the data of (A). The cellulose was sorted into three types: readily hydrolysable (orange bar), mid-hydrolysable (blue), and hardly hydrolysable (dark gray). 
was performed in a $3 \mathrm{~L}$ laboratory-scale steel cylindrical reactor equipped with a gas burner, hatch, and rotor. A chipped and ground wood sample (particle size: $0.7 \pm 0.2 \mathrm{~cm}$ ) was briefly soaked in water and added to the cylindrical reactor (filling up to one-third volume of the reactor). When the temperature and pressure inside the reactor were $220^{\circ} \mathrm{C}$ and $2.1 \mathrm{MPa}$, respectively, the hatch was immediately opened to expose the sample to the atmospheric pressure. The collected sample was stored at room temperature and used to analyze the structural effect of cellulose on the enzymatic hydrolysis rate.

Phosphoric acid (PA) was applied to popping-pretreated oak as a post-treatment. PA was prepared at a concentration of $80 \%$ and was mixed with $1 \%(\mathrm{~g} / \mathrm{v})$ popping pretreated oak. The mixture was incubated on ice for $1 \mathrm{~h}$. Centrifugation and washing were repeatedly conducted to completely remove the acid solution from the residues.

Acidified sodium chlorite (ASC) pretreatment was performed using a modified method (Nan et al., 2018). A solution of sodium chlorite $\left(0.02 \mathrm{~g} \mathrm{~mL}^{-1}\right)$ and glacial acetic acid $\left(20 \mu \mathrm{L} \mathrm{mL}^{-1}\right)$ was added to chopped oak wood, and the mixture was incubated in a water bath at $70^{\circ} \mathrm{C}$ for $\sim 30$ min until the color turned white. Centrifugation and washing with distilled water were repeatedly performed several times to remove the chemicals. The delignified sample was freeze-dried.

HPAC pretreatment was conducted using a 1:1 solution of hydrogen peroxide: acetic acid. The prepared solution was added to the wood chips which ( $100 \mathrm{~g}$ of hardwood per $1 \mathrm{~L}$ of HPAC solution), which had an average dimension of $\sim 0.2 \mathrm{~cm}$ (width) $\times$ $0.3 \mathrm{~cm}$ (height) $\times 4 \mathrm{~cm}$ (length). The mixture was incubated in a water bath at $80^{\circ} \mathrm{C}$ for $2 \mathrm{~h}$. After they were washed several times to completely remove the solution, the fibers were freeze-dried.

\section{Enzymatic Rehydrolysis}

The initial rates of enzymatic hydrolysis for the samples that were prepared via popping, PA, ASC, and HPAC treatment were analyzed. The samples $\left(1 \% \mathrm{~g} \mathrm{v}^{-1}\right)$ were hydrolyzed in $1 \mathrm{~mL}$ citrate buffer (20 mM, pH 5.0) containing 3.5 FPU cellulase $\mathrm{g}^{-1}$ biomass at $50^{\circ} \mathrm{C}$ for $1 \mathrm{~h}$. After centrifugation, the supernatant $(1 \mathrm{~mL})$ was used to measure the sugar concentration, and the pellet was briefly washed twice with a $20 \mathrm{mM}$ citrate buffer ( $\mathrm{pH} 5.0$ ) to remove soluble sugars. The pellet was repeatedly hydrolyzed and washed under the aforementioned conditions until the 6th stage, and then additional hydrolysis was performed for $2 \mathrm{~d}$ to nearly completely remove the carbohydrates from the pellet. The concentration of the reducing sugars was measured using a DNS solution ( $1 \%$ dinitrosalicylic acid, $0.05 \%$ sodium sulfite, $2 \%$ Rochelle salt, $0.2 \%$ phenol, $2 \% \mathrm{NaOH}$ ), via a method reported by Lee et al. (2014). The initial rate was calculated using the following equation:

$$
\text { Initial rate }(\%)=[S]_{\mathrm{n}} /[S]-{ }_{\mathrm{t}} \times 100
$$

where $[S]_{n}$ represents the concentration of soluble sugars in the supernatant at each stage, and $[S]_{t}$ represents the total sugar concentration, which is the sum of the sugar concentrations of the different stages and the additional reaction.

\section{Light Microscopy}

Cross-section with a rotary microtome was carried out to obtain oak sections with $60 \mu \mathrm{m}$ thickness. The sections were delignified in the ASC or HPAC solution at $80^{\circ} \mathrm{C}$ for $2 \mathrm{~h}$, and stained with $1 \%$ phloroglucinol-HCl for lignin detection. For the in-situ experiment, the cross-sections were placed on slide glass, and
A
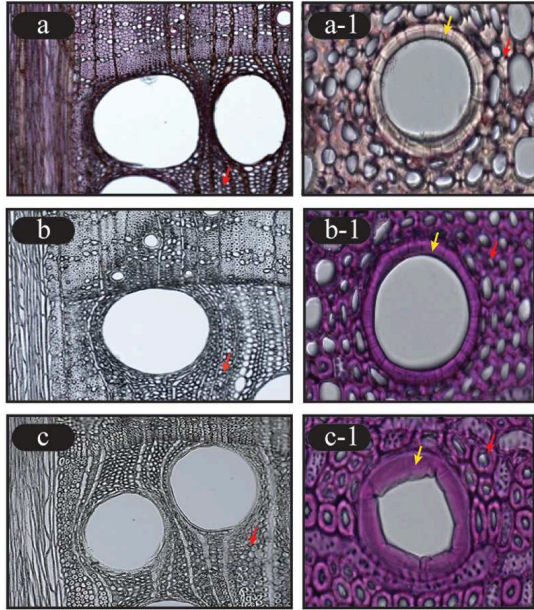

B

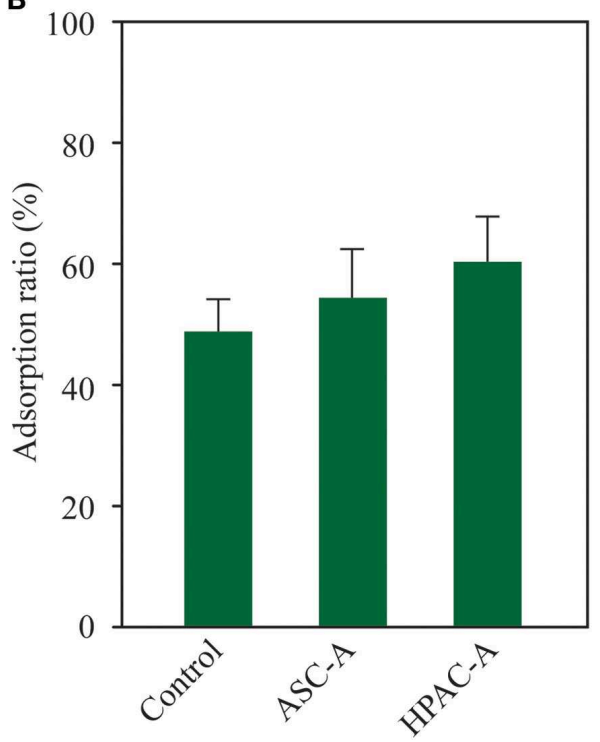

FIGURE 2 | Structural modification of cellulose. The modifications to ASC- and HPAC-pretreated oak and Avicel were determined using a light microscope and enzyme adsorption. (A) Significant cellulose swelling in the wood fibers (red arrow) and vessel elements (yellow arrow) was observed in the HPAC-pretreated oak compared with the ASC-pretreated oak. Lignin was not detected in b and c. a, control; $b$, ASC-pretreated; $c$, HPAC-pretreated. (B) Comparison of the cellulase adsorption. The control was Avicel that was not pretreated. ASC-A, ASC-treated Avicel; HPAC-A, HPAC-treated Avicel. 
hydrolyzed in $20 \mathrm{mM}$ citrate buffer (pH 5.0) with 15 FPU (100 $\left.\mu \mathrm{L} \mathrm{mL}{ }^{-1}\right)$ at $50^{\circ} \mathrm{C}$. The reactions were monitored at the same positions with a microscope (Olympus BX41) until the result of digestion was distinguishable.

\section{Enzyme Adsorption}

Avicel was incubated with ASC or HPAC solution at $80^{\circ} \mathrm{C}$ for $2 \mathrm{~h}$. After the removal of chemicals, the pretreated $5 \%$ Avicel was incubated with $1 \mathrm{~mL}$ citrate buffer $(20 \mathrm{mM}$, pH 5.0$)$ containing $15 \mathrm{FPU} \mathrm{g}^{-1}$ biomass at $50^{\circ} \mathrm{C}$ for $1 \mathrm{~h}$. The initial concentration of enzyme $[\mathrm{E}]_{\mathrm{i}}$ and the enzyme concentration of the supernatant $[\mathrm{E}]_{\mathrm{s}}$ in $1 \mathrm{~mL}$ citrate buffer were measured using the Bradford method (Bio-Rad protein assay solution, Cat. No. 500-0006, BIO-RAD, U.S) with an enzyme-linked immunosorbent assay (MULITSCAN EX, Thermo SCIENTIFIC) at $595 \mathrm{~nm}$. The concentration of the adsorbed enzymes $[\mathrm{E}]_{\mathrm{ad}}$ was calculated using the following equation: $[\mathrm{E}]_{\mathrm{ad}}=[\mathrm{E}]_{\mathrm{i}}-[E]_{\mathrm{s}}$.

\section{Enzymatic Hydrolysis of Various Hardwoods}

Hardwoods (Castanopsis sieboldii Hatus, Camellia japonica, Liriodendron tulipifera L., Quercus acuta thunb, Mallotus japonicas, Quercus acutissima, and Populus deltoides) 15$20 \mathrm{~cm}$ in diameter were chopped to prepare wood chips with dimensions of $0.2 \mathrm{~cm}$ (width) $\times 0.3 \mathrm{~cm}$ (height) $\times 4 \mathrm{~cm}$ (length), and were delignified with $\mathrm{HPAC}$ solution at $80^{\circ} \mathrm{C}$ for $2 \mathrm{~h}$. The samples (1\%) were incubated in $20 \mathrm{mM}$ citrate buffer ( $\mathrm{pH} \mathrm{5.0)}$ containing 7.5 FPU cellulase $\mathrm{g}^{-1}$ biomass at $50^{\circ} \mathrm{C}$ for $3 \mathrm{~h}$, and the concentrations of the supernatants were measured using a DNS assay. The hydrolysis rates were calculated using the equation, $[S]_{h} h^{-1}$, where $[S]_{h}$ represents the concentration of reducing sugars at the reaction time during the enzymatic saccharification.

\section{Filtration of Anatomical Xylem Tissues and Hydrolysis}

Wood fibers, tracheids, and ray parenchyma cells from HPACpretreated oak were separated via filtration with 60 and 100 mesh filters (S1020, Sigma-Aldrich). The fractions passing through the 60 and 100 mesh filters (called FPT 60 and FPT 100, respectively) were isolated. The wood fibers and tracheids that remained on the 60 mesh (fibers fraction) were harvested. The fractions were observed using a light microscope (Eclipse TE2000-U, Nikon; Olympus BX41). The samples were freeze-dried for storage at room temperature.

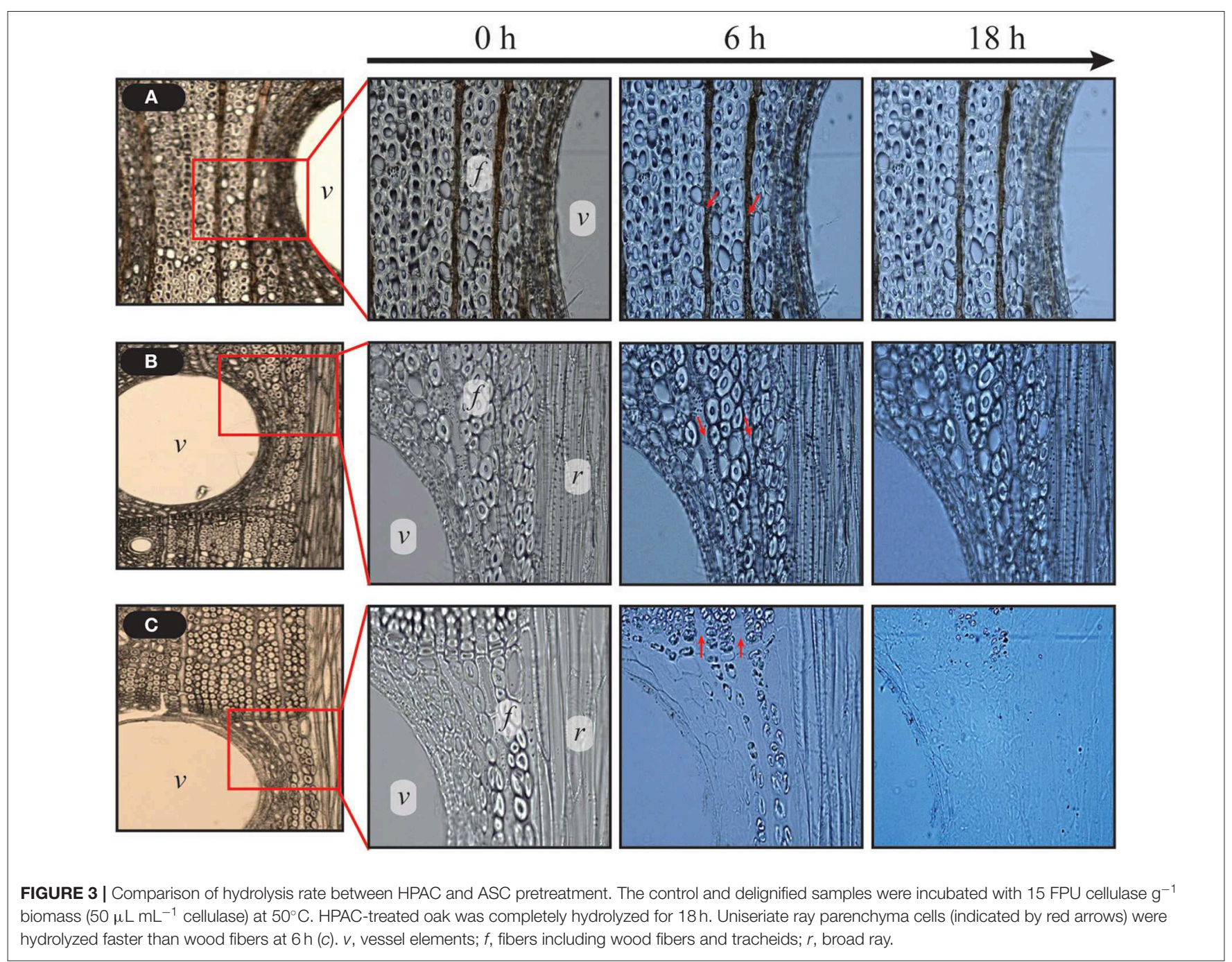


Enzymatic hydrolysis was performed in $20 \mathrm{mM}$ citrate buffer (pH 5.0) containing 0.5\% FPT 60, FPT 100, and fibers with 15 FPU cellulase $\left(100 \mu \mathrm{L} \mathrm{mL}^{-1}\right)$ at $50^{\circ} \mathrm{C}$ for $1 \mathrm{~h}$. The hydrolysis rate of the fractions was calculated using the equation $[\mathrm{S}]_{\mathrm{h}}[\mathrm{S}]_{\mathrm{t}}^{-1}$ $\mathrm{h}^{-1}$, where $[\mathrm{S}]_{\mathrm{h}}$ represents the concentration of the reducing sugars at the reaction time during enzymatic hydrolysis, and $[\mathrm{S}]_{\mathrm{t}}$ represents the concentration of total reducing sugars after $24 \mathrm{~h}$, which were almost completely hydrolyzed.

\section{Fractionation of Wood Fibers and Examination Under an Electron Microscope}

The wood fiber $\left(0.01 \mathrm{~g} \mathrm{~mL}^{-1}\right)$ was hydrolyzed with 15 FPU $\left(100 \mu \mathrm{L} \mathrm{mL} \mathrm{m}^{-1}\right)$ at $50^{\circ} \mathrm{C}$ without shaking. The fractionation was monitored with Olympus BX41 at each time point, and the fiber length was analyzed with Focus Lite ver2.90 software. The fractionated wood fibers at the appropriate reaction time were sectioned and examined using a transmission electron microscope (JEM-1400, JEOL) at an acceleration voltage of $80 \mathrm{kV}$.

\section{Saccharification and Fermentation}

A high concentration of HPAC-pretreated oak (10\%) was hydrolyzed in $20 \mathrm{mM}$ citrate buffer ( $\mathrm{pH} 5.0$ ) containing 15 or

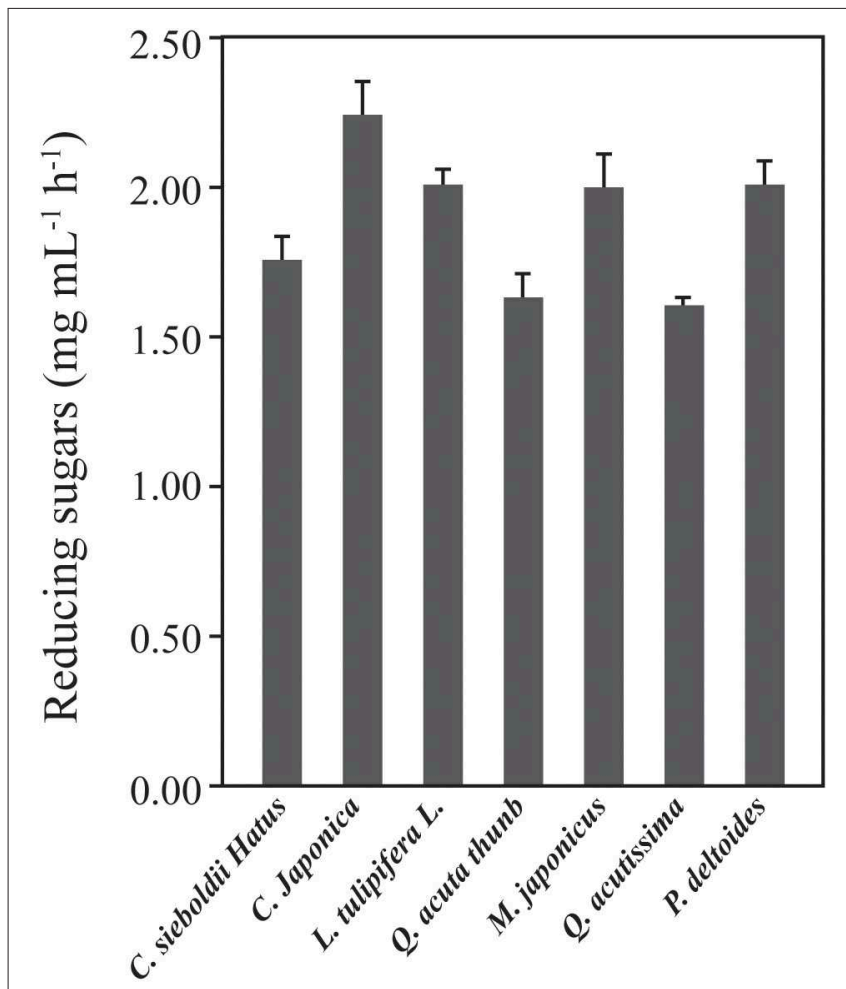

FIGURE 4 | Comparison of the initial rates of various hardwoods in enzymatic hydrolysis. The hardwoods were pretreated with the HPAC solution at $80^{\circ} \mathrm{C}$ for $2 \mathrm{~h}$ and hydrolyzed with 7.5 FPU cellulase $\mathrm{g}^{-1}$ biomass at $50^{\circ} \mathrm{C}$ for $3 \mathrm{~h}$. The hydrolysis rate of $Q$. acutissima showed the significant difference to the rate of C. sieboldii hatus, C. japonica, and L. tulipifera L., M. japonicus $(p=0.008)$ as well as $P$. deltoids $(p=<0.001)$ compared to the $Q$. acuta thunb $(p<0.800)$.
30 FPU $\mathrm{g}^{-1}$ biomass with or without supplemental enzymes (xylanase, LPMO, and betaglucosidase) at $50^{\circ} \mathrm{C}$ for $72 \mathrm{~h}$. One unit of xylanase of T. longibrachiatum was defined as the amount of enzyme required to produce $5 \mathrm{mg} \mathrm{mL}^{-1}$ reducing sugar from $1 \%$ beechwood xylan at $50^{\circ} \mathrm{C}$ in $10 \mathrm{~min}$. Beta-glucosidase $(25 \mu \mathrm{g}$ $\mathrm{mL}^{-1}$ ) completely degraded $20 \mathrm{mM}$ cellobiose at $50^{\circ} \mathrm{C}$ in $10 \mathrm{~min}$. Five units of xylanase ( $0.3 \mathrm{mg}$ LPMO per $\mathrm{g}^{-1}$ biomass) and $50 \mu \mathrm{g}$ of beta-glucosidase were loaded onto the substrate. The results were tested for significant differences on synergistic effect of between cellulase and helping enzymes, between with SigmaPlot 12.5 (Systat Software, Inc.).

Yeast powder ( $0.01 \mathrm{~g}$ of Saccharomyces cerevisiae) was inoculated in $100 \mathrm{~mL}$ of YPD solution (1\% yeast extract, $2 \%$ peptone, and $2 \%$ glucose), and cultured at $30^{\circ} \mathrm{C}$ for $12 \mathrm{~h}$. The cells were harvested, and one quarter of the cells were added to $10 \mathrm{~mL}$ of the supernatant (containing $0.1 \%$ yeast extract and $0.2 \%$ peptone) from a 1,5 , or $10 \%$ HPAC-pretreated oak (Q. acutissima) or HPAC-pretreated hardwood mixture (C. sieboldii Hatus, C. japonica, L. tulipifera L., Q. acuta thunb, M. japonicas, Q. acutissima, P. deltoids). The saccharification process was conducted with $30 \mathrm{FPU}$ cellulase $\mathrm{g}^{-1}$ biomass and the supplemental enzymes at $50^{\circ} \mathrm{C}$ for 3 days. Ethanol fermentation was performed in a shaking incubator at $200 \mathrm{rpm}$ and $30^{\circ} \mathrm{C}$ for $24 \mathrm{~h}$. The ethanol was quantified using high-performance liquid chromatography with a Rezex ROA column $\left(4.6 \times 300 \mathrm{~mm}^{2}\right.$; Phenomex, Torrance, CA, USA). Elution was performed with deionized water at a flow rate of $0.6 \mathrm{~mL} \mathrm{~min}^{-1}$ at $80^{\circ} \mathrm{C}$.

\section{RESULTS AND DISCUSSION}

\section{Pretreatment and Comparison of Cellulose Modification}

Pretreatments involving steam explosion, popping, organosolv, ASC, dilute acid, and HPAC have been developed to enhance the enzymatic hydrolysis of lignocellulosic materials for economical biofuel production. Depending on the pretreatment severity and biomass species, enzymatic hydrolysis has led to various results (from $40 \%$ to $>90 \%$ ) owing to differences in the strength of the lignin interferences and the cellulose structural recalcitrance (Zhu and Pan, 2010). Delignification of biomass by HPAC is a method used to remove the lignin interferences and change natural cellulose into an enzyme-friendly cellulose structure, which was investigated in this study. Popping pretreatment is useful for assessing lignin interferences such as adsorption of cellulase, blockage of cellulase access to cellulose fibers, and hindrance of cellulose modification during amorphogenesis. Delignification of lignocellulose, accompanied by a comparison of the hydrolysis patterns between HPAC and ASC during saccharification, can be used to evaluate the effect of the cellulose structure on enzymatic hydrolysis without lignin interferences. PA treatment can be utilized to examine the inhibitory effect of the cellulose structure in the presence of lignin. The cellulose properties were analyzed using Fourier transform infrared spectroscopy after PA or sodium hydroxide treatment, and an increase in the peak absorbance between 3,261 and $3,334 \mathrm{~cm}^{-1}$ indicated the conversion of cellulose type I to type II; the 
modified type II cellulose was readily hydrolyzed (Oh et al., 2005; Lee et al., 2014).

Oak wood was pretreated using various methods, such as popping and PA, ASC, and HPAC treatments (Figure 1) and the total reducing sugars from the $1 \%$ pretreated-oak were measured such as $4.79 \pm 0.15,5.44 \pm 0.69,5.02 \pm 0.33$, and $5.46 \pm$ $0.46 \mathrm{mg} \mathrm{mL}^{-1}$, respectively. The oak samples were repeatedly hydrolyzed for $1 \mathrm{~h}$ at $50^{\circ} \mathrm{C}$ and washed to remove end-product inhibition. The initial rate (\%) of hydrolysis at each stage in the popping-pretreated oak was $5.92 \pm 0.63$ on average. However, PA treatment for the popping-pretreated oak changed the initial rate $(\%)$ to $65.6 \pm 1.15$ (and $64.2 \pm 1.52$ for the sample that was partially hydrolyzed). The results indicate that PA treatment converts natural cellulose into a readily hydrolysable type of cellulose that has an amorphous structure (Zhang et al., 2006). The average conversion ratio was $64.9 \%$. However, the limitation of the PA treatment was that the solution was blocked from penetrating into the core of microfibrils, and the cellulose
( $\sim 23.1 \%$ ) remained as natural cellulose, the hydrolysis rate of which were $5.78 \%\left(0.35 \pm 0.12 \mathrm{mg} \mathrm{mL}^{-1}\right.$ reducing sugars $)$ on average in between 3rd and 6th stage. The cellulose was sorted into hardly hydrolysable. The hydrolysis rates of ASC and HPAC pretreated oak were not as remarkable as the results of PA treatment at the early stage of the hydrolysis, but the hydrolysis rate throughout the stages of rehydrolysis of ASC and HPAC pretreated-oak indicates different cellulose properties from the regenerated cellulose with PA (Figure 1A). In the absence of endproduct inhibition caused by xylooligomers and cellobiose, the hydrolysis rate was increased by $63.4 \%$ (Figure 1B). However, the remained $\left(1.14 \pm 0.12\right.$ or $1.05 \pm 0.02 \mathrm{mg} \mathrm{mL}^{-1}$ reducing sugars) at the last stage (6th) of $1 \%$ ASC or HPAC pretreated oak in Figure 1C were hardly hydrolysable. These results indicated that end-product inhibition has a considerable influence as a retardation factor during the early stage of enzymatic hydrolysis, while the structural recalcitrance of cellulose has a greater negative effect during the late stages.
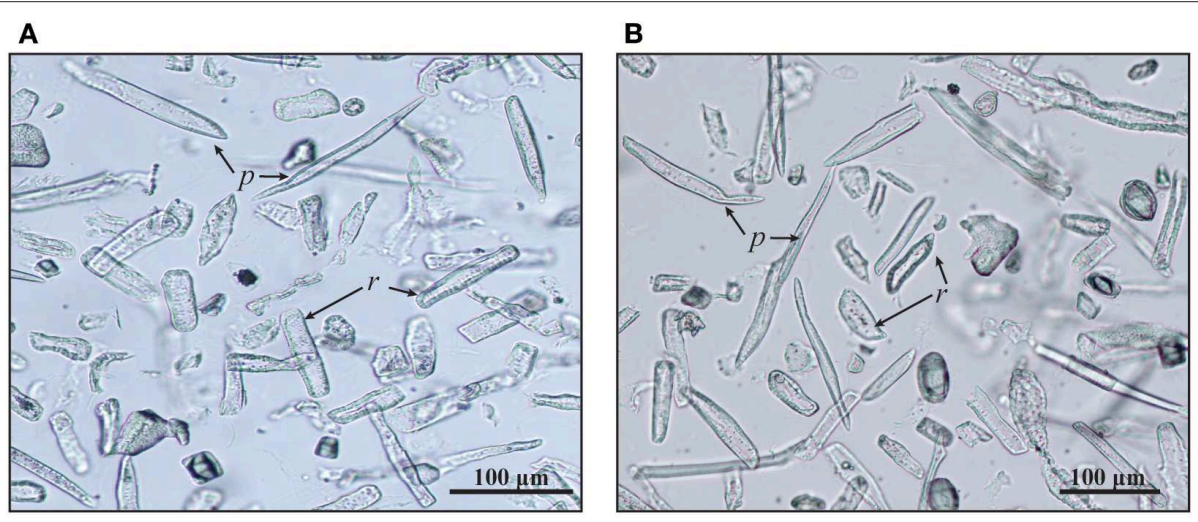

C

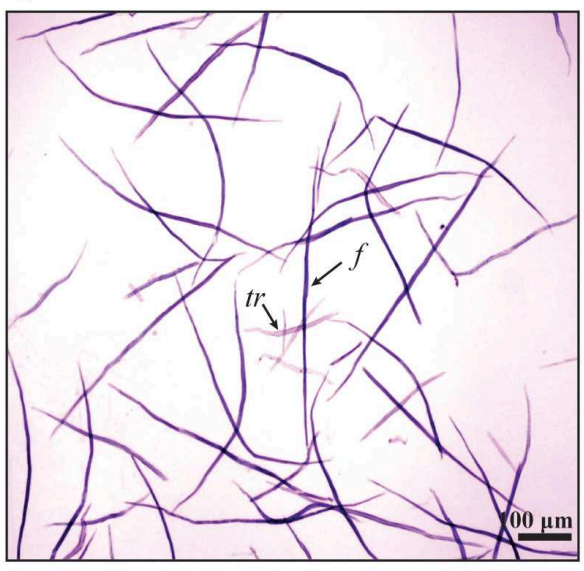

D

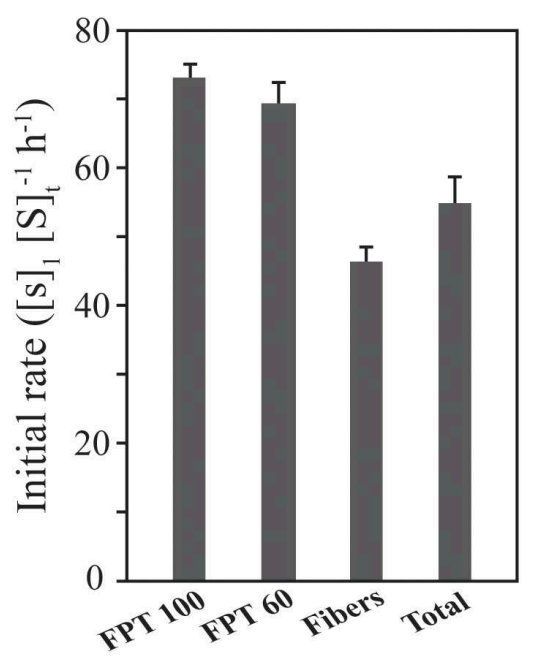

FIGURE 5 | Initial rates of anatomical tissues isolated from oak (Q. acutissima). (A) Fractions passing through the 100 mesh filter (FPT 100). (B) Fractions passing through the 60 mesh filter (FPT 60). (C) Remainder on the 60 mesh filter (including wood fibers, tracheids, and vessel elements). $f$, wood fibers; $t r$, tracheid fibers; $p$, axial parenchyma cells; $r$, ray parenchyma cells. (D) Enzymatic hydrolysis was performed in a $20 \mathrm{mM}$ citrate buffer (pH 5.0 ) containing $15 \mathrm{FPU}$ cellulase (100 $\mu \mathrm{L} \mathrm{mL}^{-1}$ ) at $50^{\circ} \mathrm{C}$ for $1 \mathrm{~h},[\mathrm{~S}]_{1}$. [S $]_{t}$ represents the total concentration of soluble sugars released from the solid substrate. 

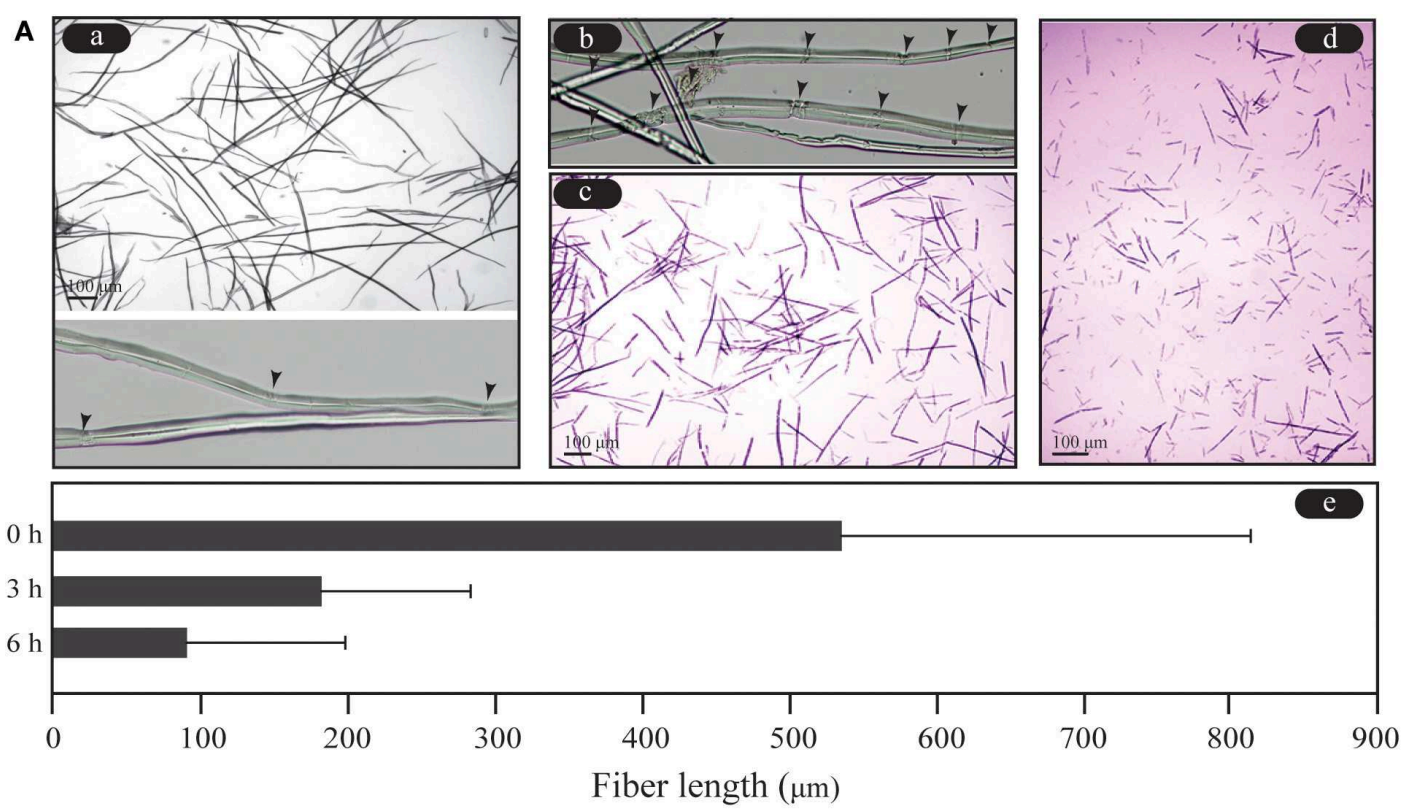
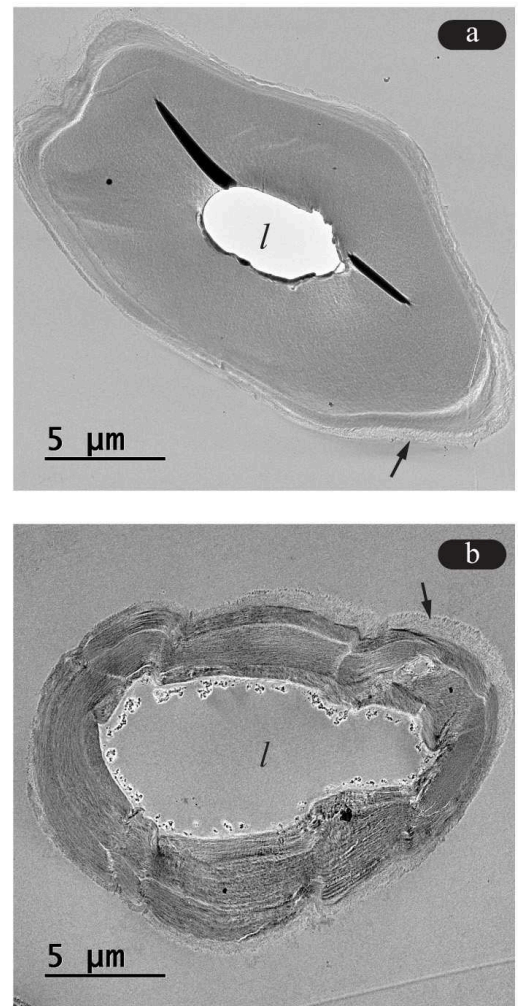

C

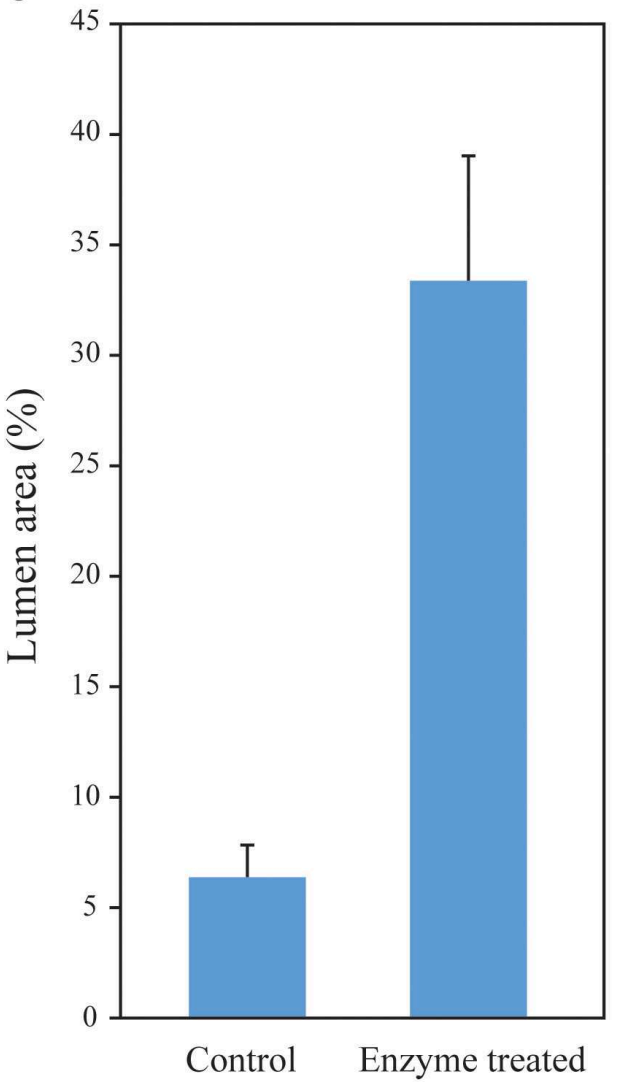

FIGURE 6 | Fiber cutting and hydrolysis patterns of wood fibers of Q. acutissima. (A) Investigation of the fiber length during enzymatic hydrolysis. Cracks (dislocation sites) and fiber cutting were observed at the early stage of the enzymatic hydrolysis. Arrow heads denote the remarkable cracks. $a, 0 \mathrm{~h} ; b, 30 \mathrm{~min} ; c, 3 \mathrm{~h} ; \mathrm{d}, 6 \mathrm{~h} ; \mathrm{e}$, comparison of fiber lengths. (B) Analysis of the hydrolysis pattern of wood fiber. Degradation occurred more rapidly in the inner part of the wood fiber than in the outer part of the fiber. The arrow and / denote the outermost (primary wall) layer of the wood fiber and lumen, respectively. a, no enzyme treatment of HPAC-treated wood fiber; $b$, enzyme-treated. (C) Ratio of the lumen area to the sectional area of the fiber. 
HPAC treatment, compared with ASC, induced significant cellulose swelling in all anatomical structures of hardwood, particularly in wood fibers and vessel elements (Figure 2A). The conversion of the crystalline structure from cellulose $I_{\alpha}$ to cellulose $\mathrm{III}_{1}$ induced greater adsorption of Cel7A in the cellulose hydrophobic region, and enhanced the hydrolysis of crystalline cellulose (Igarashi et al., 2011). An assessment of the CBM adsorption was performed to quantify the modifications of cellulose at the microfibril level (Gourlay et al., 2012). It is possible to measure the rate of cellulose structural modification at the microfiber level according to the cellulase adsorption. The cellulase was absorbed to a greater degree on HPAC-treated Avicel than that on the ASC-treated Avicel, indicating that the HPAC-treated Avicel transformed into more cellulase-friendly cellulose, such as cellulose II or III (Figure 2B). The structural modification resulted in significantly faster hydrolysis on wood fibers, vessel elements, and ray parenchyma cells in HPACtreated oak compared with ACE-treated oak (Figure 3).

\section{Hydrolysis Rate of Hardwoods}

Various hardwoods (C. sieboldii Hatus, C. japonica, L. tulipifera L., Q. acuta thunb, M. japonicas, Q. acutissima, and P. deltoids) were delignified using the HPAC method and hydrolyzed with 15 FPU cellulase $\mathrm{mL}^{-1}$ to evaluate their hydrolysis rates at the early stage of saccharification. Q. acuta thunb and $Q$. acutissima exhibited lower hydrolysis activity than the other samples (Figure 4).

\section{Anatomical Analysis of HPAC-Treated Oak}

Anatomically, hardwood consists of many tissues such as wood fibers, tracheids, ray parenchyma cells, and vessel elements in the sap and heart wood. We can assume that the tissues are composed of different amounts of lignin and xylan, in addition to various cellulose structures with different roles in the woody plant, which result in differences in the hydrolysis efficiency. However, this assumption has not been validate.

The ray parenchyma cells in Figure 3 were observed to be digested faster than the wood fibers in enzymatic hydrolysis. The tissues, including wood fibers, tracheids, ray parenchyma cells, and vessels of oak wood were separated via filtration and hydrolyzed to evaluate the hydrolysis rates of each tissue (Figure 5). The fraction passing through a 100 (FPT 100) or 60 (FPT) mesh filter mainly included ray parenchyma cells. Some debris of wood fibers and tracheids was observed in FPT 60. Intact wood fibers and tracheids were obtained from the remainder on the filter. Vessel elements were also observed in the fraction of wood fiber. The ray parenchyma cells were readily hydrolysable and exhibited a higher hydrolysis rate at the early stage than the wood fibers. The tracheid were digested faster than the wood fibers (Supplementary Figure 1). The vessel elements of early and late wood were hydrolyzed more rapidly than the wood fibers and tracheids (Supplementary Figure 2). According to the results, the hydrolysis rates of the oak tissues decreased in the following order: ray parenchyma cells $>$ tracheids $>$ wood fibers, or vessel elements $>$ tracheids $>$ wood fibers.

\section{Hydrolysis of Wood Fiber}

Wood fiber was digested less than the other tissues in the HPACpretreated oak, making it a structural retardation factor during enzymatic hydrolysis. The hydrolysis mechanism of wood fiber has been studied at the supramolecular level, with a focus on dislocation sites that cause changes in microfibril orientation within the S1 layer of softwood tracheids (Clarke et al., 2011; Thygesen et al., 2011; Arantes et al., 2014). Cellulase, particularly endo-glucanase, binds to the dislocation sites on softwood tracheids and wheat straw fiber, resulting in fiber cutting. It was suggested that fiber cutting occurs in crystalline regions rather than amorphous regions, in contrast to what has been assumed
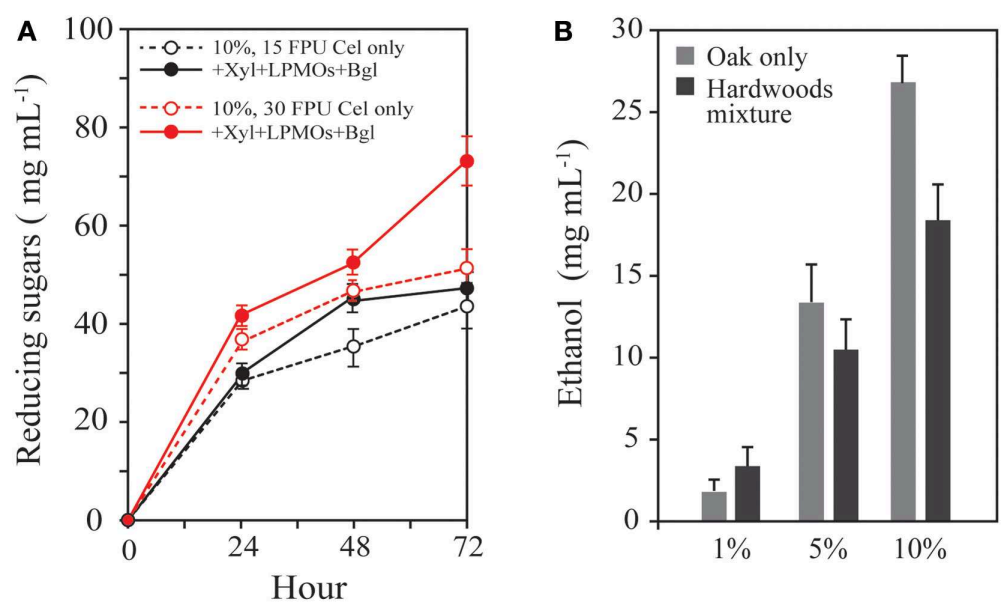

FIGURE 7 | Synergistic effect depending on the cellulase concentration and fermentation efficiency of hardwoods. (A) HPAC-pretreated oak (10\%) was hydrolyzed with 15 or $30 \mathrm{FPU}$ cellulase $\mathrm{g}^{-1}$ biomass. Supplementation with xylanases, beta-glucosidase, and LPMOs was performed to minimize the end-product inhibition and structural recalcitrance of cellulose. The 30 FPU cellulase-based cocktail solution caused $52.92 \pm 0.78 \%$ increment of reducing sugars from the substrate $(p=<$ 0.001), but $5.27 \pm 2.32 \%$ increment in the $15 \mathrm{FPU}$ cocktail solution $(p=0.36)$ compare to the each basal enzyme. (B) Bioethanol production from the oak $(Q$. acutissima) only and the hardwood mixture (C. sieboldii Hatus, C. japonica, L. Tulipifera L, Q. acuta thunb, M. japonicas, Q. acutissima, and P. deltoides). 
thus far (Thygesen et al., 2011). Cracks on the fibers of the HPAC-pretreated oak, which were assumed to be dislocation sites, were observed before addition of cellulase (Figure 6A). The cracks remarkably appeared during the initial stage of the reaction (after $30 \mathrm{~min}$ with cellulase, Figure 6A-b). Fiber cutting was observed to account for $66.09 \%$ of the fractionated fibers $<200 \mu \mathrm{m}$ in length and $33.9 \%$ of the fractionated fibers between 200 and $500 \mu \mathrm{m}$ in length at $3 \mathrm{~h}$. At $6 \mathrm{~h}$, the ratios of fractionated fibers $<100 \mu \mathrm{m}$ and length was $100-300 \mu \mathrm{m}$ in length were 74.30 and $25.70 \%$, respectively. The fiber cutting of the HPACpretreated oak occurred and finished during the initial stage of hydrolysis, similar to the pretreatment of pulp fibers using steam or organosolv methods (Clarke et al., 2011).

As shown in Figure 2, the wood fibers swelled with HPAC pretreatment. This caused the HPAC-treated oak to be hydrolyzed significantly faster than the samples treated using ASC methods. The lumen of the wood fiber was rapidly enlarged by the cellulose, while the outer layers of the fiber were shrunken by the cellulase (Figures 6B,C). The lignin removal and swelling strength of the secondary wall in the wood fibers may have been stronger toward the lumen, resulting in a loosened cellulose structure of the $S_{2}$ or $S_{3}$ layer in the secondary wall, which led to faster degradation of the inner part of the secondary wall in the wood fiber compared with the outer layer (primary wall or $S_{1}$ ).

\section{Enhancement of Hydrolysis Rate and Production of Bioethanol From Hardwoods}

High concentrations of the insoluble solid substrate are needed to achieve significantly higher fermentative production through efficient enzymatic saccharification and fermentation processes. However, saccharification at a high concentration of the solid substrate is faced with enzyme-related retardation factors, such as end-product inhibition and substrate-related physical recalcitrance of cellulose. In the enzymatic hydrolysis of $10 \%$ HPAC-pretreated oak, the former was expected to occur throughout the enzymatic hydrolysis of the lignocellulosic biomass, whereas the latter may have occurred significantly at late stages, according to the results shown in Figure 1C. Xylooligomers are strong inhibitors on Cel7A (Qing et al., 2010). The inhibitor is inferred to be dominant during the early stage, similar to cellobiose (Murphy et al., 2013). LPMO is known to be a powerful oxidative enzyme that breaks down the recalcitrance of cellulose via modifications of the microfibril cellulose chain network (Eibinger et al., 2014; Villares et al., 2017). LPMOs played a remarkable role in hydrolysis with cellulase on cellulose I rather than cellulose II and III (Hu et al., 2014). It is assumed that LPMOs are needed to achieve synergy with cellulase on HPAC-pretreated oak during the late stages. HPAC-pretreated oak $(10 \%)$ was hydrolyzed with 15 or 30 FPU cellulase $\mathrm{g}^{-1}$ biomass, and 43.33 or $47.85 \mathrm{mg} \mathrm{mL}^{-1}$ reducing sugars were produced for $72 \mathrm{~h}$ (Figure 7). For enhancing the saccharification efficiency, supplementation with xylanases and beta-glucosidase was performed to minimize the end-product inhibition as well as supplementation with LPMOs to reduce the structural recalcitrance of cellulose, resulting in the production of 43.54 and $74.27 \mathrm{mg} \mathrm{mL}^{-1}$ reducing sugars, respectively. A significant increment was observed for the 30 FPU cellulase cocktail solution (55.21\%) ( $p=<0.001)$ but not for the 15 FPU enzyme solution $(p=0.36)$. This indicates that the induction of the synergistic effect on the high concentration of the hardwood required a significantly larger amount of cellulase (30 FPU cellulase in this study) to efficiently reduce the inhibition effects related to the enzymatic and substrate physical inhibitions. To achieve costeffective saccharification of the hardwood, a further study may be needed to obtain a better understanding of the synergy between LPMOs and the cellulose structural recalcitrance at the late stage of hydrolysis caused by the recalcitrance of the primary wall. The fermentation for ethanol production was carried out using fermentable sugars produced from mixtures of 1,5 , and 10\% HPAC-pretreated oak and hardwoods including C. sieboldii Hatus, C. japonica, L. Tulipifera L, Q. thunb, M. japonicas, Q. acutissima, and $P$. deltoides. More ethanol was produced from a single substrate than from the mixture at a high concentration.

\section{CONCLUSION}

Hardwoods can be utilized for biofuels and biochemical production. However, research on hardwoods has not been conducted intensively compared with that on softwoods. We investigated the cellulose properties that are changed by HPAC pretreatment and analyzed the initial rate of tissues such as wood fibers, tracheids, vessel elements, and ray parenchyma cells to compare their recalcitrance. The wood fiber, which was the most hardly digestible, was fragmented into small pieces and finished at an early stage. The wood fiber was degraded faster at the $S_{3}$ and $S_{2}$ walls of the lumen site than at the primary wall of the outer part. The results indicate that the primary wall of wood fiber is the main structural retardation factor during enzymatic hydrolysis of HPAC-pretreated oak. Supplementation with xylanases, LPMO, and beta-glucosidase enhanced the hydrolysis rate $(55.21 \%)$ at a high concentration of hardwood. Bioethanol was produced at $26.81 \mathrm{mg} \mathrm{mL}^{-1}$ from 10\% HPAC-pretreated oak for $24 \mathrm{~h}$.

\section{DATA AVAILABILITY STATEMENT}

All datasets generated for this study are included in the article/Supplementary Material.

\section{AUTHOR CONTRIBUTIONS}

D-SL performed the experiments and analysis of data, and drafted the manuscript. E-JC carried out sugar quantification through HPLC analysis. YS prepared ASC- and HPACpretreatment oak. Y-GL produced cellulolytic and xylolytic enzymes. H-JB designed the project, critically analyzed the data and improved the manuscript. All authors and approved the final manuscript.

\section{FUNDING}

This research was supported by the National Research Foundation of Korea (NFR) grant funded by the Korea government (MSIP) (No. 2018R1A2A2A05018238) and by Basic Science Research Program through the National Research Foundation of Korea (NRF) funded by the Ministry of Education (2017R1A6A3A11034355). 


\section{SUPPLEMENTARY MATERIAL}

The Supplementary Material for this article can be found online at: https://www.frontiersin.org/articles/10.3389/fenrg. 2020.00034/full\#supplementary-material

Supplementary Figure 1 | The wood and tracheid fibers, remained on the 60 mesh, were hydrolyzed with $15 \mathrm{FPU} \mathrm{mL} \mathrm{mL}^{-1}$ in Tissue Culture Plate 96 well at $50^{\circ} \mathrm{C}$.

\section{REFERENCES}

Arantes, V., Gourlay, K., and Saddler, J. N. (2014). The enzymatic hydrolysis of pretreated pulp fibers predominantly involves "peeling/erosion" modes of action. Biotechnol. Biofuels 7:87. doi: 10.1186/1754-68 34-7-87

Baumann, M., Borch, K., and Westh, P. (2011). Xylan oligosaccharides and cellobiohydrolase I $(\operatorname{TrCel7A})$ interaction and effect on activity. Biotechnol. Biofuels 4:45. doi: 10.1186/1754-6834-4-45

Cara, C., Ruiz, E., Ballesteros, I., Negro, M. J., and Castro, E. (2006). Enhanced enzymatic hydrolysis of olive tree wood by steam explosion and alkaline peroxide delignification. Process. Biochem. 41, 423-429. doi: 10.1016/j.procbio.2005.07.007

Chundawat, S. P. S., Lipton, M. S., Purvine, S. O., Uppugundla, N. U., Gao, D., Balan, V., et al. (2011). Proteomics-based compositional analysis of complex cellulase-hemicellulase mixtures. J. Proteome. Res. 10, 4365-4372. doi: $10.1021 /$ pr101234z

Clarke, K., Li, X., and Li, K. (2011). The mechanism of fiber cutting during enzymatic hydrolysis of wood biomass. Biomass. Bioenergy 35, 3943-3950. doi: 10.1016/j.biombioe.2011.06.007

Eibinger, M., Ganner, T., Bubner, P., Rosker, S., Kracher, D., Haltrich, D., et al. (2014). Cellulose surface degradation by a lytic polysaccharide monooxygenase and its effect on cellulase hydrolytic efficiency. J. Biol. Chem. 289, 35929-35938. doi: 10.1074/jbc.M114.602227

Gourlay, K., Arantes, V., and Saddler, J. N. (2012). Use of substructurespecific carbohydrate binding modules to track changes in cellulose accessibility and surface morphology during the amorphogenesis step of enzymatic hydrolysis. Biotechnol. Biofuels 5:51. doi: 10.1186/1754-68 34-5-51

Gruno, M., Valjamae, P., Pettersson, G., and Johansson, G. (2004). Inhibition of the Trichoderma reesei cellulases by cellobiose is strongly dependent on the nature of the substrate. Biotechnol. Bioeng. 86, 503-511. doi: 10.1002/bit. 10838

Hall, M., Bansal, P., Lee, J. H., Realff, M. J., and Bommarius, A. S. (2010). Cellulose crystallinity- a key predictor of the enzymatic hydrolysis rate. FEBS J. 277, 1571-1582. doi: 10.1111/j.1742-4658.2010.07585.x

Herpoel-Gimbert, I., Margeot, A., Dolla, A., Jan, G., Molle, D., Lignon, S., et al. (2008). Comparative secretome analyses of two Trichoderma reesei RUT-C30 and CL847 hypersecretory strains. Biotechnol. Biofuels 1:18. doi: $10.1186 / 1754-6834-1-18$

Hu, J., Arantes, V., Pribowo, A., Gourlay, K., and Saddler, J. N. (2014). Substrate factors that influence the synergistic interaction of AA9 and cellulase during the enzymatic hydrolysis of biomass. Energy. Envion. Sci. 7, 2308-2315. doi: 10.1039/C4EE00891J

Igarashi, K., Uchihashi, T., Koivula, A., Mad, M., Kumura, S., Okamoto, T., et al. (2011). Traffic jams reduce hydrolytic efficiency of cellulase on cellulose surface. Science 333, 1279-1282. doi: 10.1126/science.1208386

Igarashi, K., Wada, M., and Samejima, M. (2007). Activation of crystalline cellulose to cellulose IIII results in efficient hydrolysis by cellobiohydrolases. FEBS J. 274, 1785-1792. doi: 10.1111/j.1742-4658.2007.05727.x

Kumar, L., Chandra, R., and Saddler, J. (2011). Influence of steam pretreatment severity on post-treatments used to enhance the enzymatic hydrolysis of pretreated softwoods at low enzyme loadings. Biotechnol. Bioeng. 108, 2300-3211. doi: 10.1002/bit.23185

Lee, D. S., Wi, S. G., Lee, S. J., Lee, Y. G., Song, Y., and Bae, H. J. (2014). Rapid saccharification for production of cellulosic biofuels.
The fibers were monitored using a microscope (Eclipse TE2000-U, Nikon). a, 0 min; $b, 40$ min; c, 120 min; $d, 180$ min.

Supplementary Figure 2 | The fraction of wood and tracheid fibers contains vessel elements such as large vessel member (A) and elongated vessel member (B). The vessel elements were monitored to compare with the degradation rate of wood fibers. The vessel elements were observed to be degraded faster than tracheid and wood fiber. The hydrolysis was carried out with $15 \mathrm{FPU} \mathrm{mL}^{-1}$ at $50^{\circ} \mathrm{C}$. $a, 0 \mathrm{~min} ; b, 10 \mathrm{~min} ; \mathrm{c}, 20 \mathrm{~min}$. $f$, wood fiber; $t r$, tracheid; $v$, vessel elements.
Bioresour. Technol. 158, 239-247. doi: 10.1016/j.biortech.2014 02.039

Monica, E. K., Goran, G., and Gunnar, H. (2009). Pulp and Paper Chemistry and Technology, Vol. 1, Wood Chemistry and Wood Biotechnology. Berlin: Walter de Gruyter, 46-70.

Murphy, L., Bohlin, C., Baumann, M. J., Olsen, S. N., Sorensen, T. H., Anderson, L., et al. (2013). Product inhibition of five Hypocrea jecorina cellulases. Enzyme. Microb. Technol. 52, 163-169. doi: 10.1016/j.enzmictec.2013.01.002

Nan, Y., Jia, L., Yang, M., Xin, D., Qin, Y., and Zhang, J. (2018). Simplified sodium chlorite pretreatment for carbohydrates retention and efficient enzymatic saccharification of silvergrass. Bioresour. Technol. 216, 223-231. doi: 10.1016/j.biortech.2018 03.106

Oh, S. Y., Yoo, D. I., Shin, Y., Kim, H. C., Kim, H. Y., Chung, Y. S. et al. (2005). Crystalline structure analysis of cellulose treated with sodium hydroxide and carbon dioxide by means of X-ray diffraction and FTIR spectroscopy. Carbohydr. Res. 304, 2376-2391. doi: 10.1016/j.carres.2005. 08.007

Qing, Q., Yang, B., and Wyman, C. E. (2010). Xylooligomers are strong inhibitors of cellulose hydrolysis by enzymes. Bioresour. Technol. 101, 9624-9630. doi: 10.1016/j.biortech.2010.06.137

Rahikainen, J., Mikander, S., Marjamaa, K., Tamminen, T., Lappas, A., Viikari, L., et al. (2011). Inhibition of enzymatic hydrolysis by residual lignins from softwood- study of enzyme bionding and inactivation on lignin-rich surface. Biotechnol. Bioeng. 108, 2823-2834. doi: 10.1002/bit. 23242

Taylor, F. W. (1968). Variations in the size and proportions of wood elements in yellow-poplar trees. Wood. Sci. Technol. 2, 153-165.

Teugjas, H., and Valjamae, P. (2013). Product inhibition of cellulases studied with ${ }^{14} \mathrm{C}$-labeled cellulose substrates. Biotechnol. Biofuels 6:104 doi: 10.1186/1754-6834-6-104

Thygesen, L. G., Hidayat, B. J., Johansen, K. S., and Felby, C. (2011). Role of supramolecular cellulose structures in enzymatic hydrolysis of plant cell walls. J. Ind. Microbiol. Biotechnol. 38, 975-983. doi: 10.1007/s10295-0100870-y

Valjamae, P., Sild, V., Pettersson, G., and Johansson, G. (1998). The initial kinetics of hydrolysis by cellobiohydrolases I and II is consistent with a cellulose surface- erosion model. Eur. J. Biochem. 253, 469-475. doi: 10.1046/j.1432-1327.1998.2530469.x

Vermaas, J. V., Petridis, L., Qi, X., Schulz, R., Lindner, B., and Smith, J. C. (2015). Mechanism of lignin inhibition of enzymatic biomass deconstruction. Biotechnol. Biofuels 8:217. doi: 10.1186/s13068-015-0379-8

Villares, A., Moreau, C., Bennati-Granier, C., Garajova, S., Foucat, L., Falourd, X., et al. (2017). Lytic polysaccharide monooxygenases disrupt the cellulose fibers structure. Sci. Rep. 7, 1-9. doi: 10.1038/srep40262

Wi, S. G., Cho, E. J., Lee, D. S., Lee, S. J., Lee, Y. J., and Bae, H. J. (2015). Lignocellulose conversion for biofuel: a new pretreatment greatly improves downstream biocatalytic hydrolysis of various lignocellulosic materials. Biotechnol. Biofuels 8:228. doi: 10.1186/s13068-015-0419-4

Wi, S. G., Chung, B. Y., Lee, Y. G., Yang, D. J., and Bae, H. J. (2011) Enhanced enzymatic hydrolysis of rapeseed straw by popping pretreatment for bioethanol production. Bioresour. Technol. 102, 5788-5793. doi: 10.1016/j.biortech.2011.02.031

Yue, Z., Bin, W., Baixu, Y., and Peiji, G. (2004). Mechanism of cellobiose inhibition in cellulose hydrolysis by cellobiohydrolases. Sci. China Life Sci. 47, 18-24. doi: $10.1360 / 02 y c 0163$ 
Zhang, X., Qu, T., Mosier, N. S., Han, L., and Xiao, W. (2018). Cellulose modification by recyclable swelling solvents. Biotechnol. Biofuels 11:191. doi: 10.1186/s13068-018-1191-Z

Zhang, Y. H., Cui, J., Lynd, L. R., and Kuang, L. R. (2006). A transition from cellulose selling to cellulose dissolution by o-phosphoric acid: evidence from enzymatic hydrolysis and supramolecular structure. Biomacromolecules 7, 644-648. doi: 10.1021/bm050799c

Zhu, J. Y., and Pan, X. J. (2010). Woody biomass pretreatment for cellulosic ethanol production: Technology and energy consumption evaluation. Bioresour. Technol. 10, 4992-5002. doi: 10.1016/j.biortech.2009. 11.007
Conflict of Interest: The authors declare that the research was conducted in the absence of any commercial or financial relationships that could be construed as a potential conflict of interest.

Copyright (c) 2020 Lee, Lee, Song, Cho and Bae. This is an open-access article distributed under the terms of the Creative Commons Attribution License (CC BY). The use, distribution or reproduction in other forums is permitted, provided the original author(s) and the copyright owner(s) are credited and that the original publication in this journal is cited, in accordance with accepted academic practice. No use, distribution or reproduction is permitted which does not comply with these terms. 